\title{
CHEMICAL COMPOSITION, ANTIOXIDANT ACTIVITY AND CYTOTOXIC EFFECTS OF ROMANIAN CRATERELLUS CORNUCOPIOIDES (L.) PERS. MUSHROOM
}

\author{
TEODORA COSTEA ${ }^{1 \#}$, ARIANA HUDIŢA ${ }^{2 \#}$, OCTAVIAN TUDOREL OLARU ${ }^{3 \#}$, BIANCA \\ GĂLĂŢEANU ${ }^{2 *}$, CERASELA ELENA GÎRD ${ }^{1}$, MARIA-MAGDALENA MOCANU ${ }^{4}$ \\ 1 "Carol Davila” University of Medicine and Pharmacy, Faculty of Pharmacy, Department of Pharmacognosy, \\ Phytochemistry and Phytotheraphy, 020956 Bucharest, Romania \\ ${ }^{2}$ University of Bucharest, Department of Biochemistry and Molecular Biology, 050095 Bucharest, Romania \\ 3 "Carol Davila" University of Medicine and Pharmacy, Faculty of Pharmacy, Department of Pharmaceutical Botany and \\ Cellular Biology, 020956 Bucharest, Romania \\ 4 "Carol Davila” University of Medicine and Pharmacy, Department of Biophysics, 050474 Bucharest, Romania
}

*corresponding author: bianca.galateanu@gmail.com

\#Authors with equal contribution.

Manuscript received: September 2019

\begin{abstract}
The aim of our paper was the evaluation of chemical composition, antioxidant activity and cytotoxic effects of several dry extracts obtained from black trumpet wild mushroom. Phytochemical analysis of sterols and total phenolic content were determined by means of spectrophotometric methods. The antioxidant activity was assessed by scavenger activity towards DPPH (2,2-diphenyl-1-picrylhydrazyl), ABTS $^{++}$(2,2'-azinobis-(3-ethylbenzothiazoline-6-sulfonic acid) free radicals, ferric reducing power and ferrous ions chelating properties. For cytotoxicity evaluation, Daphnia magna bioassay, MTT (3-(4,5dimethylthiazol-2-yl)-2,5-diphenyltetrazolium bromide) and live and dead viability assays have been used. The aqueous dry extract had the highest phenolic content and generally the best antioxidant activity. Alcoholic dry extracts showed similar sterols content. The highest cytotoxic activity upon Daphnia magna crustaceans and human epidermoid carcinoma A431 cells was observed for alcoholic dry extracts. Overall, all extracts showed antioxidant activity. Further pharmacological research is needed in order to determine the potential anticancer effects of the analysed extracts and their exact mechanism of action.
\end{abstract}

\section{Rezumat}

Scopul lucrării a constat în determinarea compoziţiei chimice, evaluarea activităţii antioxidante şi a citotoxicităţii unor extracte uscate provenite de la ciuperca indigenă Craterellus cornucopioides (L.) Pers. (trompeta neagră). Conţinutul de polifenoli totali şi steroli a fost determinat prin metode spectrofotometrice. Activitatea antioxidantă a urmărit capacitatea de scavenger a radicalilor liberi 2,2-difenil-1-picrilhidrazil (DPPH), acidului 2,2-azino-bis-(3-etil-benzotiazolin-6-sulfonic) $\left(\right.$ ABTS $\left.^{*+}\right)$, capacitatea de reducere şi chelatare a ferului. Citotoxicitatea extractelor a fost evaluată pe baza testelor Daphnia magna, MTT [bromură de 3-(4,5-dimetiltiazol-2-il)-2,5-difeniltetrazoliu], respectiv live and dead. În general, extractul apos a manifestat cea mai puternică acţiune antioxidantă şi cel mai mare conţinut de polifenoli totali. Extractele alcoolice au un conţinut asemănător de steroli. Extractele alcoolice au manifestat efect citotoxic pronunţat asupra celulelor de carcinom epidermoid A431 şi asupra crustaceului Daphnia magna. Toate extractele analizate au efect antioxidant. Sunt necesare cercetări farmacologice viitoare în vederea stabilirii profilului antitumoral al extractelor obținute.

Keywords: polyphenols, antioxidant capacity, sterols, cellular viability

\section{Introduction}

For the last few decades, mushrooms have been used both as food (due to their high nutritional value) and medicine [6, 14, 16, 18, 19, 28, 38]. According to current estimates, mushrooms constitute at least 12,000 species worldwide and out of that 2000 species are reported as edible [27]. Mushrooms contain a great variety of bioactive compounds which provide a great assortment of biological effects (antioxidant, immunomodulatory, anticancer, antimicrobial, anti-inflammatory or hypoglycaemic) [24, 30, 33, 38].
Among edible mushrooms, Craterellus cornucopioides (L.) Pers., commonly known as horn of plenty, black cantherelle or black trumpet is wide spread throughout Europe and North America [17]. It is an unmistakable species, due to the distinctive black thin trumpets with a smooth to faintly wrinkled hymenium [17]. Regarding its chemical composition, black cantherelle is an important source of $\beta$-glucans [25], polyunsaturated fatty acids, aminoacids, phenolic compounds [21], sequiterpenoids [12], sterols [40], minerals [37], organic acids [2] and stilbenes [39]. 
The mushroom exhibits antioxidant, antimicrobial [5, 25], antihyperglycemic [21] and hypocholesterolemic [10] activities.

The aim of our research was to perform and assess the chemical composition, antioxidant activity and cytotoxic effects of several black trumpet dry extracts.

\section{Materials and Methods}

\section{Materials}

Whole dried fruiting-bodies of Craterellus cornucopioides (L.) Pers. were acquired in 2017, from a specific Romanian manufacturer.

Reagents and solvents

All chemicals were purchased from Sigma-Aldrich (Germany). The viability/cytotoxicity assay kit for animal live and dead cells was purchased from Invitrogen (USA).

Preparation of dry extracts

$20 \mathrm{~g}$ of dried black trumpet were heated twice with $200 \mathrm{~mL}$ solvent (water or $80 \%$ ethanol or $80 \%$ methanol) on a reflux condenser for $30 \mathrm{~min}$. The combined filtrates were evaporated under reduced pressure at $40^{\circ} \mathrm{C}$ (Buchi R210-215 rotary evaporator) and then, freeze-dried (Christ Alpha 1-2/B Braun, BiotechInternational lyophilizator). The extracts were encoded as follows: EE (freeze-dried $80 \%$ ethanolic extract), EM (freeze-dried 80\% methanolic extract) and EA (freeze-dried aqueous extract). The extraction yield (\%) was expressed as the percentage of the total mass of dry extract with respect to the mass of the mushroom loaded for the initial extraction [41].

Preparation of samples for spectrophotometric and antioxidant assays

One g of EE, EM and EA dry extracts were dissolved in $100 \mathrm{~mL}$ solvent (80\% ethanol; $80 \%$ methanol; water). For all determinations a Jasco V-530 (Jasco, Japan) spectrophotometer have been used.

Spectrophotometric determination of total phenolic content

Total phenolic content was determined with FolinCiocâlteu reagent, as previously described $[11,26]$. Results were expressed as g gallic acid/100 g dry extract, based on a calibration curve $(1.22-7.22 \mu \mathrm{g} / \mathrm{mL}$, $\mathrm{R}^{2}=0.9989, \mathrm{n}=6$ ).

Spectrophotometric determination of free sterols Free sterols were determined based on their dehydration in the presence of perchloric acid and vanillin acetate, as previously described [22]. Results were expressed as g ergosterol/100 g dry extract, based on a calibration curve $\left(5.18-31.12 \mu \mathrm{g} / \mathrm{mL}, \mathrm{R}^{2}=0.9900\right.$, $\mathrm{n}=6$ ).

\section{Antioxidant capacity}

The antioxidant capacity was evaluated by means of well-known methods - the scavenger activity towards 2,2-diphenyl-1-picrylhydrazyl (DPPH), 2,2'-azinobis(3-ethylbenzothiazoline-6-sulfonic acid) $\left(\mathrm{ABTS}^{++}\right)$ free radicals, ferric reducing power and chelating activity upon ferrous ions. These methods have been also used by other authors for antioxidant activity evaluation of medicinal mushrooms [36]. For each method determinations were carried on according to previously described methods $[11,26]$. The concentration range was $0.2-1.8 \mathrm{mg} / \mathrm{mL}$ (for DPPH and ferric reducing power methods), $0.04-1 \mathrm{mg} / \mathrm{mL}$ (for $\mathrm{ABTS}^{\circ+}$ assay) and $0.4-2 \mathrm{mg} / \mathrm{mL}$ (for ferrous metal chelating activity). The antioxidant capacity was assessed by means of ascorbic acid equivalents (for DPPH, $\mathrm{ABTS}^{\circ+}$ and ferric reducing power methods) and $\mathrm{Na}_{2}$-EDTA equivalents for ferrous ions chelating activity, as previously described [26].

Cytotoxic activity

The cytotoxic activity of the analysed dry extracts was determined by means of Daphnia magna, MTT (3(4,5-dimethylthiazol-2-yl)-2,5-diphenyltetrazolium bromide) and live and dead bioassays.

Daphnia magna bioassay

The method consists in exposure of crustaceans to serial dilutions of the dry extracts (concentration range $100-2000 \mu \mathrm{g} / \mathrm{mL}$ ) and counting the survivors after 24, 48 and 72 hours incubation. Samples were prepared and analysed as previously described [8, 11].

Cell culture models and extracts treatment (for MTT and live and dead assays)

Human dermal fibroblasts CCD-1070 Sk cells and human epidermoid carcinoma A431cells were cultured in Dulbecco`s Modified Eagle Medium (DMEM) supplemented with $10 \%$ foetal bovine serum (FBS) and $1 \%$ penicillin - streptomycin mix. Both cell lines were maintained in standard conditions at $37^{\circ} \mathrm{C}$ in a humidified atmosphere with $5 \% \mathrm{CO}_{2}$ and sub-cultured weekly. For all experiments, cells were detached from culture vessels by enzymatic treatment with trypsin/ EDTA and seeded in 96-well plates for MTT assay and 6-well plates for microscopy studies at an initial density of $2 \times 10^{4}$ cells $/ \mathrm{cm}^{2}$. After $24 \mathrm{~h}$ of culture, the culture medium was removed and replaced with the appropriate treatments.

Preparation of samples

$0.01 \mathrm{~g}$ of each dry extract were dissolved in $10 \mathrm{~mL}$ dimethyl sulfoxide (DMSO) (stock solution). The stock solutions were sequentially sterilized by $0.22 \mu \mathrm{M}$ syringe filtration and further used for obtaining the working dilutions $\left(\mathrm{D}_{1}-0 \mu \mathrm{g} / \mathrm{mL}, \mathrm{D}_{2}-6.25 \mu \mathrm{g} / \mathrm{mL}\right.$, $\mathrm{D}_{3}-12.5 \mu \mathrm{g} / \mathrm{mL}, \mathrm{D}_{4}-25 \mu \mathrm{g} / \mathrm{mL}, \mathrm{D}_{5}-50 \mu \mathrm{g} / \mathrm{mL}$, $\mathrm{D}_{6}-75 \mu \mathrm{g} / \mathrm{mL}, \mathrm{D}_{7}-100 \mu \mathrm{g} / \mathrm{mL}, \mathrm{D}_{8}-200 \mu \mathrm{g} / \mathrm{mL}$, $\left.\mathrm{D}_{9}-500 \mu \mathrm{g} / \mathrm{mL}, \mathrm{D}_{10}-1000 \mu \mathrm{g} / \mathrm{mL}\right)$ using MiliQ sterilized water.

MTT assay

The assay is based on the assumption that MTT tetrazolium salt reduction to its formazan (which is violet coloured) occurs only in the mitochondria of living cells due to the activity of mitochondrial dehydrogenases [32]. MTT is one of the most popular tests to assess the potential anticancer effect of different compounds/herbal or mushroom extracts [32]. Briefly, 
after $24 \mathrm{~h}$ and $72 \mathrm{~h}$ of culture, the culture medium was removed and the monolayers were incubated for $4 \mathrm{~h}$ with $1 \mathrm{mg} / \mathrm{mL}$ fresh MTT solution at $37^{\circ} \mathrm{C}$, allowing metabolically active cells to form formazan crystals. The formazan crystals were further solubilized in isopropanol and the concentration of the resultant solution was spectrophotometrically quantified at $550 \mathrm{~nm}$ using the multimodal reader Flex Station III (Molecular Devices) [23, 31].

Live and dead assay

This fluorescence based method of assessing cell viability employs two probes that detect intracellular esterase activity in live cells (the esterase substrate calcein-AM stains live cells in green) and compromised plasma membrane integrity in dead cells (ethidium homodimer III stains dead cells in red) [34]. Live and dead assay was performed according to Ghali $\mathrm{W}$ et al. [9]. Briefly at the end of the experimental time (after 24 and $72 \mathrm{~h}$ ), the culture medium was removed and the monolayers were washed with phosphate buffer saline (PBS) and then stained for 15 minutes at room temperature and darkness with a fresh solution of calcein - AM and ethidium bromide, prepared according to the manufacture`s provided protocol. For highlighting live and dead cells, all samples were analysed by fluorescence microscopy using an Olympus IX73 fluorescence inverted microscope and CellSens Imaging Software for image capture and edit.

Statistical analysis

For each dry extract, three samples were analysed and spectrophotometric, antioxidant and cytotoxic assays were carried out in triplicate. Results are presented as mean \pm standard deviation (SD) and were statistically analysed using GraphPad Prism 6 software, using one-way ANOVA test with Bonferroni correction or

Tukey post-test. A value of $\mathrm{p}<0.05$ was considered the threshold for a statistically significant difference.

\section{Results and Discussion}

Solvents with different polarities (ethanol 80\%; methanol $80 \%$ and water) have been used for dry extracts preparation, since the solvent is a key factor that influences mushrooms active substances extraction $[1,25]$. According to our results (Table I) the aqueous dry extract (EA) has a significantly $(\mathrm{p}<0.05)$ higher total phenolic content compared to EE or EM extracts. Our results are in agreement with other authors research, that found a higher total phenolic content for Agaricus bisporus, Trametes versicolor, Inonotus hispidus or Hydnellum ferugineum aqueous extracts compared to alcoholic ones [1, 25, 33]. We assume that the higher phenolic content of EA dry extract is the consequence of gallic acid and glycosidic forms of caffeic and p-coumaric acids presence [21]. Still, it is well-known that phenolic compounds are usually more soluble in alcoholic solutions rather than aqueous ones, so we assume that EA higher phenolic content might be the consequence of other compounds (aminoacids, proteins or glycosides) interaction with FolinCiocâlteu reagent [3]. Our results, regarding total phenolic content of EE and EM dry extracts are lower compared to other authors that found $4.39 \mathrm{~g}$ gallic $\mathrm{acid} / 100 \mathrm{~g}$ ethanolic dry extract and $2.63 \mathrm{~g}$ gallic $\mathrm{acid} / 100 \mathrm{~g}$ methanolic dry extract respectively [5, 25]. Regarding free sterols content (Table I), EM and EE have a similar content, which is in agreement with other authors, who demonstrated that alcohol (methanol/ethanol) and n-hexane are the best solvents for ergosterol extraction from mushrooms [40].

Table I

Total phenolic content of analysed dry extracts

\begin{tabular}{ccc}
\hline Dry extract & Extraction yield (\%) & Total phenolic content (g gallic acid/100 g dry extract) \\
\hline EE & 24.13 & $1.1234 \pm 0.0966$ \\
\hline EM & 23.09 & $1.1938 \pm 0.0969$ \\
\hline EA & 29.13 & $2.7527 \pm 0.1727$ \\
\hline
\end{tabular}

Results are mean \pm SD $(n=3)$. EE - 80\% ethanolic dry extract; EM - 80\% methanolic dry extract; EA- aqueous dry extract

Our results regarding the in vitro antioxidant activity (Table II) showed that the EA dry extract has the best and statistically significant scavenger activity $(\mathrm{p}<0.05)$ towards DPPH and $\mathrm{ABTS}^{\bullet+}$ free radicals. As shown in Figure 1a, the scavenger activity towards DPPH free radical at the highest concentration $(1.8 \mathrm{mg} / \mathrm{mL})$ was $70.95 \%$ for EA, $34.83 \%$ for EE and $48.7 \%$ for EM. Dry extracts have also scavenged ABTS ${ }^{\circ+}$ free radical in a dose-dependent manner. The extracts displayed scavenging activity with values ranging from $97.15 \%$ for EA to $86.45 \%$ for $\mathrm{EE}$ and $85.21 \%$ for EM (Figure 1b). Concerning the ferric reducing power, for the $1.8 \mathrm{mg} / \mathrm{mL}$ dilution, the registered absorbance was 0.6539 in the case of EA dry extract and only 0.3577 for EM and 0.2945 for the EE extracts (Figure $2 \mathrm{a}$ ). We assume that $\beta$-glucans, phenolic compounds and minerals are responsible for EA significant antioxidant activity [21, 25]. For ferrous ions chelating activity (Figure 2b.) the results were unexpected, since EM dry extract showed a significant ( $p<0.05$ ) higher antioxidant activity compared to EA and EE extracts. Probably, the surprising results are the consequence of a higher solubilisation of organic acids in methanol [2]. 
Table II

Acid ascorbic/ $\mathrm{Na}_{2}$-EDTA equivalents for analysed extracts

\begin{tabular}{ccccc}
\hline \multirow{2}{*}{ Dry extract } & \multicolumn{4}{c}{ ANTIOXIDANT ASSAYS (mg ascorbic acid/g dry extract or mg Na -EDTA /g dry extract) } \\
\cline { 2 - 5 } & DPPH & ABTS $^{++}$ & Ferric reducing power & Chelating activity \\
\hline EE & $18.1050 \pm 0.7443$ & $295.34 \pm 0.4906$ & $4.2750 \pm 0.2629$ & $35.1287 \pm 0.8974$ \\
\hline EM & $20.1487 \pm 0.7872$ & $273.13 \pm 0.5861$ & $5.5682 \pm 1.0493$ & $66.59 \pm 0.7418$ \\
\hline EA & $27.6787 \pm 0.8780$ & $559.29 \pm 0.1967$ & $17.3972 \pm 1.7329$ & $40.46 \pm 0.3143$ \\
\hline
\end{tabular}

Results are mean \pm SD $(n=3)$. EE - 80\% ethanolic dry extract; EM - 80\% methanolic dry extract; EA - aqueous dry extract

Daphnia magna bioassay (Table III) has shown that all extracts induced high lethality $(100 \%)$ from the first $24 \mathrm{~h}$ on the crustaceans at higher concentrations (over $1000 \mu \mathrm{g} / \mathrm{mL}$ for EA and over $750 \mu \mathrm{g} / \mathrm{mL}$ for

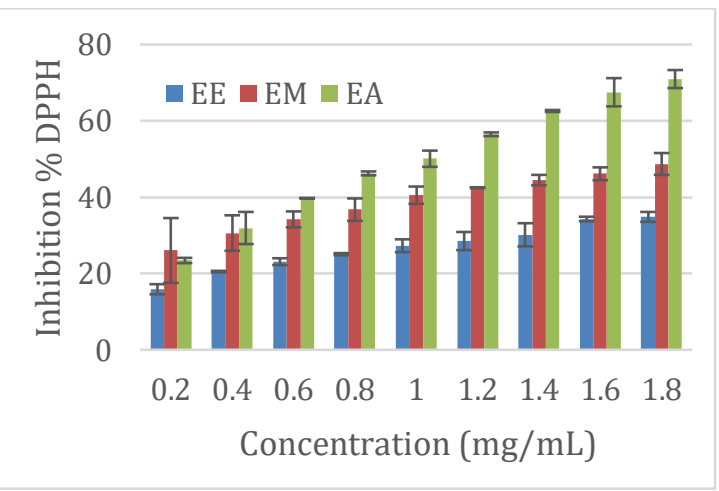

a
EE and EM). EA dry extract induced a moderate to low toxicity on D. magna, whereas EE and EM extracts induced a moderate to high toxicity.

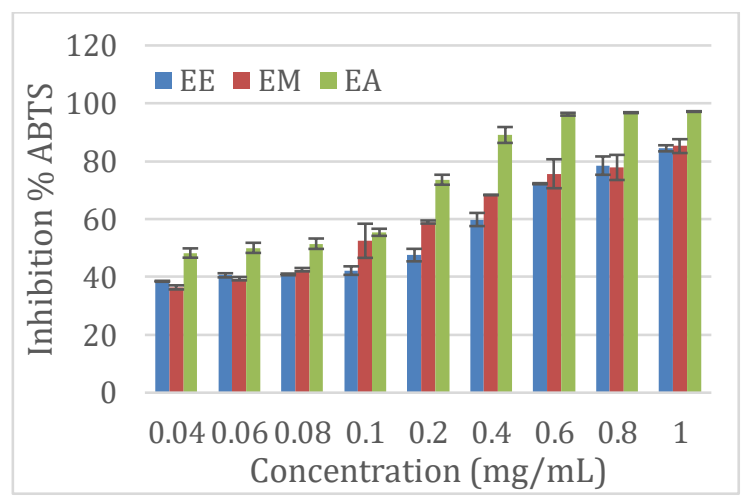

$\mathrm{b}$

Figure 1.

Evaluation of antioxidant activity - a (DPPH assay), b (ABTS ${ }^{\bullet+}$ assay)

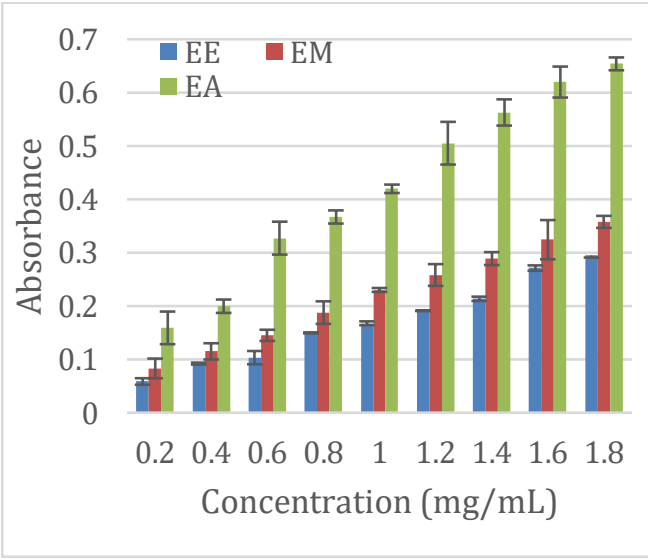

a

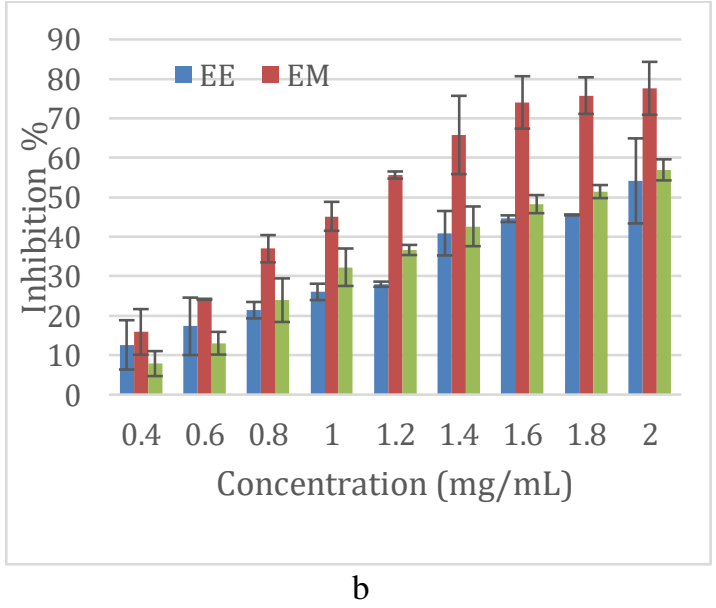

Figure 2.

Evaluation of antioxidant activity - a (ferric reducing power), b (chelating activity)
EM extracts. We assume that phenolic compounds (quercetin), sterols (ergosterol and ergosterol peroxide) and sesquiterpenoids (illudin type) are responsible for the EE and EM marked cytotoxic effects [12, 15, 21].

Table III

Results of Daphnia magna bioassay

\begin{tabular}{ccccccc}
\hline $\begin{array}{c}\text { Dry } \\
\text { extract }\end{array}$ & $\begin{array}{c}\mathbf{L C 5 0}_{\mathbf{2 4}} \\
(\boldsymbol{\mu} \mathbf{g} / \mathbf{m L})\end{array}$ & $\begin{array}{c}\mathbf{C I 9 5 \% ~ o f ~ L C 5 0 ~}_{\mathbf{2 4}} \\
(\boldsymbol{\mu} \mathbf{g} / \mathbf{m L})\end{array}$ & $\begin{array}{c}\mathbf{L C 5 0}_{\mathbf{4 8}} \\
(\boldsymbol{\mu g} / \mathbf{m L})\end{array}$ & $\begin{array}{c}\mathbf{C I 9 5 \% ~ o f ~ L C 5 0 ~}_{\mathbf{4}} \\
(\boldsymbol{\mu} \mathbf{g} / \mathbf{m L})\end{array}$ & $\begin{array}{c}\mathbf{L C 5 0}_{\mathbf{7 2}} \\
(\boldsymbol{\mu g} / \mathbf{m L})\end{array}$ & $\begin{array}{c}\mathbf{C I 9 5 \% ~ o f ~} \mathbf{L C 5 0}_{\mathbf{7 2}} \\
(\boldsymbol{\mu g} / \mathbf{m L})\end{array}$ \\
\hline EA & 525.1 & $\mathrm{NC}$ & 516.2 & $\mathrm{NC}$ & 339.7 & NC \\
\hline EE & 209 & $\mathrm{NC}$ & 198.8 & $\mathrm{NC}$ & 112 & 101.3 to 123.8 \\
\hline EM & 208 & 188.8 to 229.1 & 160.7 & 152.7 to 169.2 & 130.8 & 115.8 to 147.7 \\
\hline
\end{tabular}

Legend: $\mathrm{EE}-80 \%$ ethanolic dry extract; EM - 80\% methanolic dry extract; EA - aqueous dry extract. LC50 - 50\% lethal concentration, 95\% CI $-95 \%$ confidence interval, $\mathrm{NC}-$ not calculated due to the obtained results 
Cytotoxicity screening of the tested mushroom extracts on the CCD-1070 Sk and A431 cells, using MTT assay (Figure 3) revealed that after $24 \mathrm{~h}$ of treatment, none of the three extracts alter cellular viability regardless of the used treatment dose or cell type. In contrast, after $72 \mathrm{~h}$ of treatment a significant effect $(p<0.05)$ of the tested mushroom extracts is observed upon cell viability of both cell lines (Figure 3).

CELL LINE

A431

CCD-1070sK

EE DRY EXTRACT
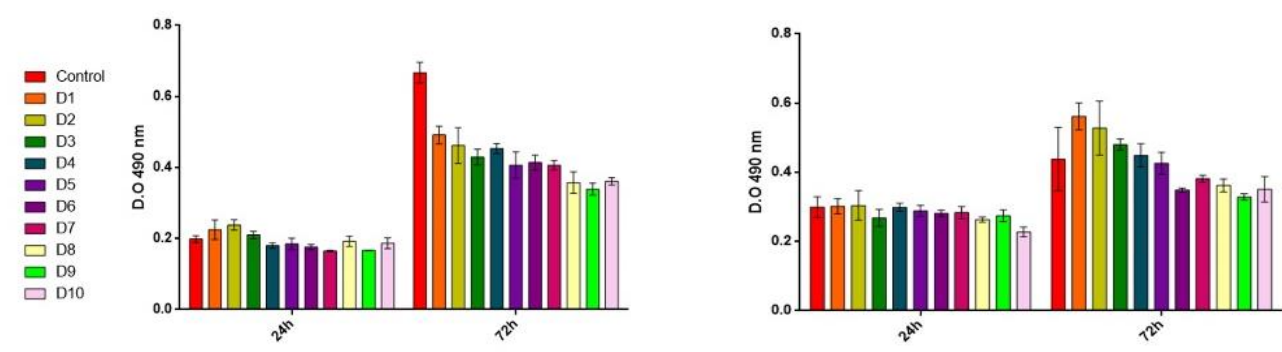

EM DRY EXTRACT
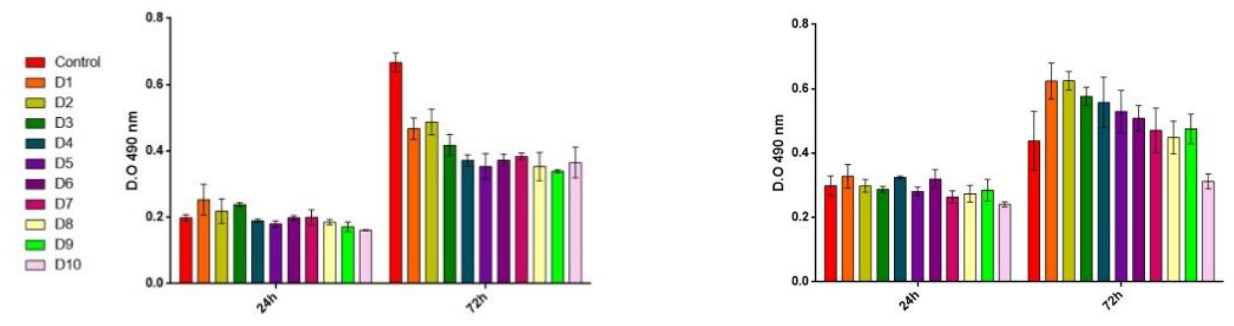

EA DRY EXTRACT
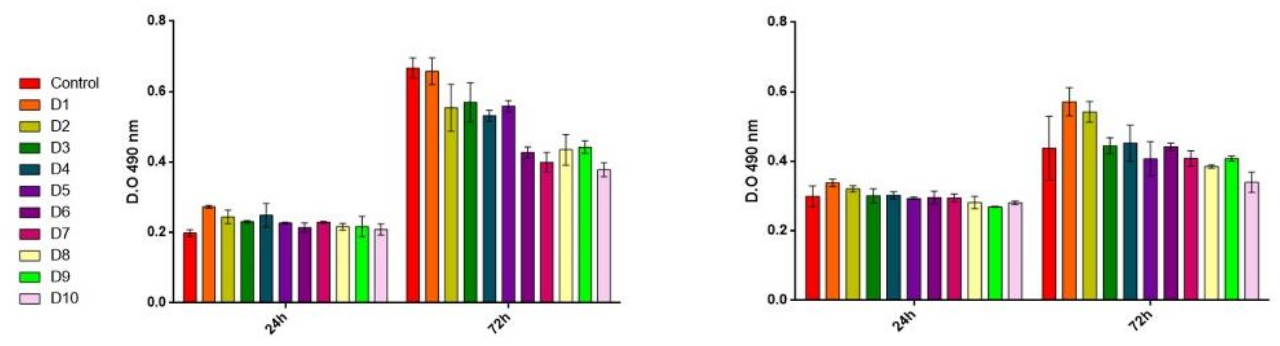

Figure 3.

Results of MTT assay

$\left(\mathrm{D}_{1}-0 \mu \mathrm{g} / \mathrm{mL}, \mathrm{D}_{2}-6.25 \mu \mathrm{g} / \mathrm{mL}, \mathrm{D}_{3}-12.5 \mu \mathrm{g} / \mathrm{mL}, \mathrm{D}_{4}-25 \mu \mathrm{g} / \mathrm{mL}, \mathrm{D}_{5}-50 \mu \mathrm{g} / \mathrm{mL}, \mathrm{D}_{6}-75 \mu \mathrm{g} / \mathrm{mL}, \mathrm{D}_{7}-100 \mu \mathrm{g} / \mathrm{mL}\right.$, $\mathrm{D}_{8}-200 \mu \mathrm{g} / \mathrm{mL}, \mathrm{D}_{9}-500 \mu \mathrm{g} / \mathrm{mL}, \mathrm{D}_{10}-1000 \mu \mathrm{g} / \mathrm{mL}$; EE - 80\% ethanolic dry extract; EM - 80\% methanolic dry extract; EA - aqueous dry extract)

For CCD-1070 Sk cell line, all extracts trigger an increase of cellular viability as compared with the untreated control (Figure 3). In contrast, A431 tumour cells viability significantly decrease after exposure to all mushrooms extracts (Figure 3). For EE and EM dry extracts, the decrease of A431 cell viability is dose-dependent, the cytotoxic effect being more pronounced at high concentrations. For EA dry extract, at high concentrations no significant effect on A431 cell viability is observed. However, at low doses of extract a significantly decrease of A431 cell viability is noticed most likely due to Hormesis effect.

Results for live and dead cells test are correlated with MTT assay, since after $24 \mathrm{~h}$ of treatment, the presence of dead cells is not observed neither in CCD-1070 Sk cells, nor in A431 cells, regardless the used extract or dose applied. Interestingly, even if very few dead red cells are present in A431 cells exposed to different concentrations of dry extracts (after $72 \mathrm{~h}$ ), most of the A431 cells are viable bright green cells, but the ratio of viable cells is obviously low as compared with the untreated control (Figures 4, 5).

These results suggest that most probably the extracts alter the proliferation capacity of the A431 tumour cells. We assume that polysaccharides are mainly responsible for the selective cytotoxicity of the analysed dry extracts upon A431 tumour cells. $\beta$-glucans are regarded as biological response modifiers, that enhance 
the innate and adaptive immune systems and stimulate tumour rejection. These polysaccharides activate dectin-1 receptor (a non-Toll-like pattern recognition receptor that is expressed on myeloid cells, macrophages or neutrophils), which leads to maturation of dendritic cells both in vitro and in vivo and enhanced antigenspecific CD4 and CD8T-cell responses [35].

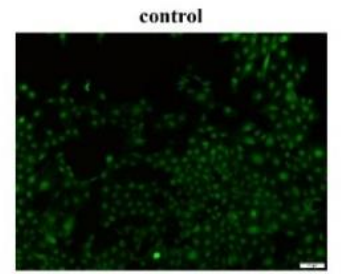

D3

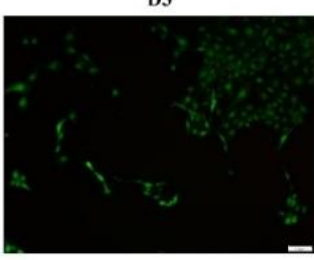

D7

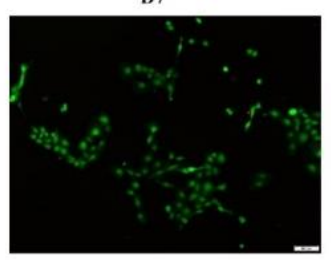

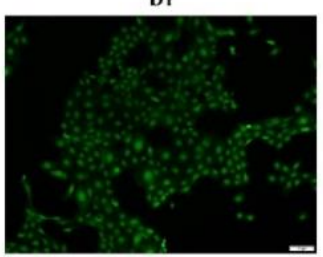

D4

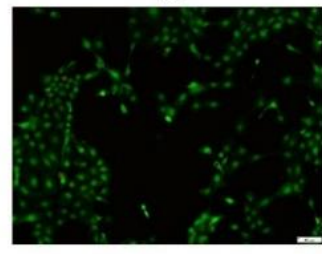

D8

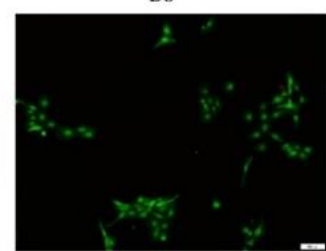

D2

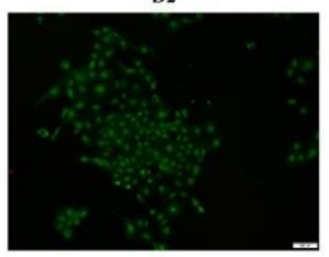

D5

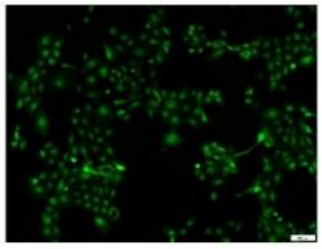

D9

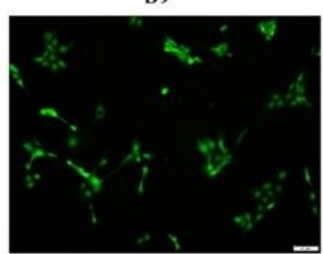

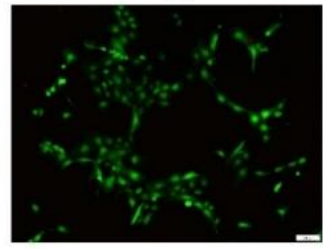

D10

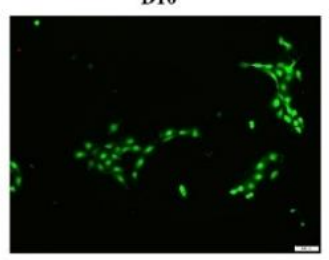

Figure 4.

Fluorescence micrographs of A431 cells after $72 \mathrm{~h}$ of treatment with EE dry extract at different concentrations $\left(\mathrm{D}_{1}-0 \mu \mathrm{g} / \mathrm{mL}, \mathrm{D}_{2}-6.25 \mu \mathrm{g} / \mathrm{mL}, \mathrm{D}_{3}-12.5 \mu \mathrm{g} / \mathrm{mL}, \mathrm{D}_{4}-25 \mu \mathrm{g} / \mathrm{mL}, \mathrm{D}_{5}-50 \mu \mathrm{g} / \mathrm{mL}, \mathrm{D}_{6}-75 \mu \mathrm{g} / \mathrm{mL}, \mathrm{D}_{7}-100 \mu \mathrm{g} / \mathrm{mL}\right.$, $\mathrm{D}_{8}-200 \mu \mathrm{g} / \mathrm{mL}, \mathrm{D}_{9}-500 \mu \mathrm{g} / \mathrm{mL}, \mathrm{D}_{10}-1000 \mu \mathrm{g} / \mathrm{mL}$; EE - 80\% ethanolic dry extract; EM - 80\% methanolic dry extract; EA - aqueous dry extract)

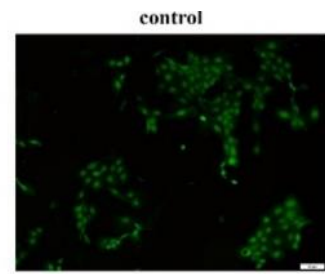

D3

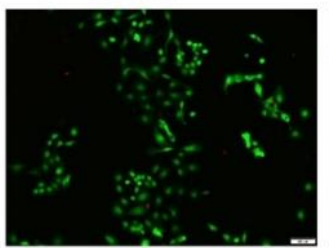

D7

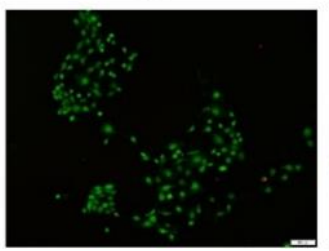

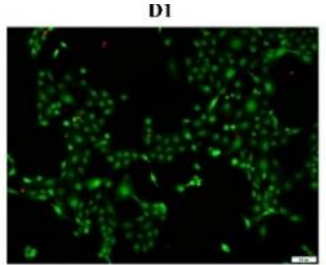

D4

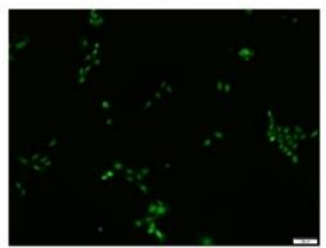

D8

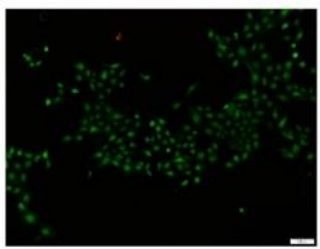

D2

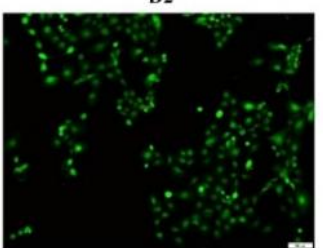

D5

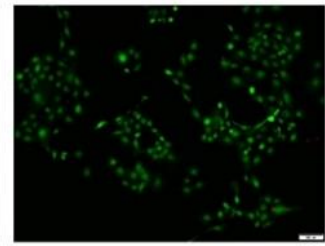

D9

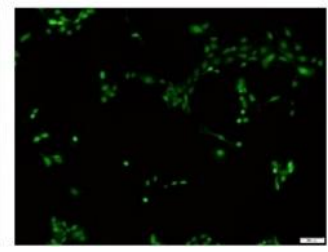

D6

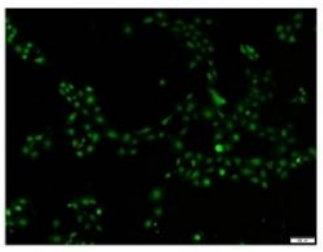

D10

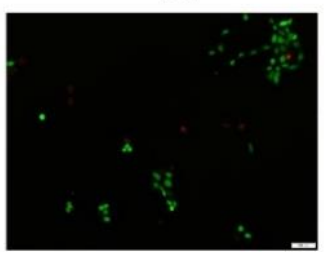

Figure 5.

Fluorescence micrographs of A431 cells after $72 \mathrm{~h}$ of treatment with EA dry extract at different concentrations

$\left(\mathrm{D}_{1}-0 \mu \mathrm{g} / \mathrm{mL}, \mathrm{D}_{2}-6.25 \mu \mathrm{g} / \mathrm{mL}, \mathrm{D}_{3}-12.5 \mu \mathrm{g} / \mathrm{mL}, \mathrm{D}_{4}-25 \mu \mathrm{g} / \mathrm{mL}, \mathrm{D}_{5}-50 \mu \mathrm{g} / \mathrm{mL}, \mathrm{D}_{6}-75 \mu \mathrm{g} / \mathrm{mL}, \mathrm{D}_{7}-100 \mu \mathrm{g} / \mathrm{mL}\right.$, $\mathrm{D}_{8}-200 \mu \mathrm{g} / \mathrm{mL}, \mathrm{D}_{9}-500 \mu \mathrm{g} / \mathrm{mL}, \mathrm{D}_{10}-1000 \mu \mathrm{g} / \mathrm{mL}$; EE - 80\% ethanolic dry extract; EM - 80\% methanolic dry extract; EA - aqueous dry extract) 
Moreover, $\beta$-glucans downregulate the expression of myeloid-derived suppressor cells, which play a major role in tumour-induced immunosuppression [35]. Other compounds (reported by scientific literature for black trumpet mushroom) that might be involved in mushroom extracts cytotoxicity are illudin type sesquiterpenoids (which act as DNA alkylating agents) [12, 15]; ergosterol (which up-regulates tumour suppressor Foxo 3 and apoptosis) [20] or stilbens (piceatannol which promotes apoptosis through upregulation of microRNA-181a) [7, 39]. Moreover phenolic compounds (quercetin, gallic acid, caffeic acid) act as anticancer agents due to pro-oxidant activity, mitochondrial toxicity, cell cycle arrest, caspase activation and increase of $\mathrm{Bax} / \mathrm{Bcl}-2$ ratio $[4,13,21,29]$.

\section{Conclusions}

Overall, analysed dry extracts from Craterellus cornucopioides (L.) Pers. (black trumpet) mushroom are a source of bioactive compounds with antioxidant activity. The aqueous dry extract had the highest total phenolic content and the best antioxidant activity (as determined by DPPH, ABTS $^{++}$and ferric reducing power assays). Alcoholic dry extracts are an important source of free sterols. The cytotoxic activity upon Daphnia magna crustaceans decreased as follows $\mathrm{EE} \sim \mathrm{EM}>\mathrm{EA}$. All analysed dry extracts have shown a selective cytotoxic effect towards human epidermoid A431 tumour cells. Further pharmacological research is needed in order to determine the potential anticancer effects of analysed dry extracts and their exact mechanism of action.

\section{Conflict of interest}

The authors declare no conflict of interest.

\section{References}

1. Abugri DA, McElhenney WH, Extraction of total phenolic and flavonoids from edible wild and cultivated medicinal mushrooms as affected by different solvents. J Nat Prod Plant Resour., 2013; 3(3): 37-42.

2. Barros L, Pereira C, Ferreira IC, Optimized analysis of organic acids in edible mushrooms from Portugal by ultra fast liquid chromatography and photodiode array detection. Food Anal. Methods, 2013; 6(1): 309-316.

3. Bastola KP, Guragain YN, Bhadriraju V, Vadlani PV, Evaluation of standards and interfering compounds in the determination of phenolics by Folin-Ciocalteu assay method for effective bioprocessing of biomass. Am J Analyt Chem., 2017; 8(06): 416-431.

4. Damasceno SS, Dantas BB, Ribeiro-Filho J, Araújo AM, da Costa GM, Chemical properties of caffeic and ferulic acids in biological system: implications in cancer therapy. A review. Curr Pharm Des., 2017; 23(20): 3015-3023.

5. Dimitrijevic M, Jovanovic VS, Cvetkovic J, MihajilovKrstev T, Stojanovic G, Mitic V, Screening of antioxidant, antimicrobial and antiradical activities of twelve selected Serbian wild mushrooms. Anal Methods, 2015; 7(10): 4181-4191.

6. Drori A, Shabat Y, Ben Ya'acov A, Danay O, Levanon D, Zolotarov L, Ilan Y, Extracts from Lentinula edodes (Shiitake) edible mushrooms enriched with vitamin D exert an anti-inflammatory hepatoprotective effect. J Med Food, 2016; 19(4): 383-389.

7. Du M, Zhang Z, Gao T, Piceatannol induced apoptosis through up-regulation of microRNA-181a in melanoma cells. Biol Res., 2017; 50(1): 1-10.

8. Fan W, Cui M, Liu H, Wang C, Shi Z, Tan C, Yang $\mathrm{X}$, Nano-TiO2 enhances the toxicity of copper in natural water to Daphnia magna. Environ Pollut., 2011; 159: 729-734.

9. Ghali W, Vaudry D, Jouenne T, Marzouki MN, Lycium Europaeum fruit extract: antiproliferative activity on A549 human lung carcinoma cells and PC12 rat adrenal medulla cancer cells and assessment of its cytotoxicity on cerebellum granule cells. Nutrition and cancer, 2015; 67(4): 637-646.

10. Gil-Ramírez A, Clavijo C, Palanisamy M, RuizRodríguez A, Navarro-Rubio M, Pérez M, Marin FR, Reglero G, Soler-Rivas C, Screening of edible mushrooms and extraction by pressurized water (PWE) of 3-hydroxy-3-methyl-glutaryl CoA reductase inhibitors. J Funct Foods, 2013; 5(1): 244-250.

11. Gird CE, Duţu LE, Costea T, Nencu I, Popescu ML, Olaru OT, Preliminary research concerning the obtaining of herbal extracts with potential neuroprotective activity. Note I. Obtaining and characterization of a selective Origanum vulgare L. dry extract. Farmacia, 2016; 64(5): 680-687.

12. Guo H, Diao QP, Hou D Y, Li ZH, Zhou ZY, Feng T, Liu JK, Sesquiterpenoids from cultures of the edible mushroom Craterellus cornucopioides. Phytochem Lett., 2017; 21: 114-117.

13. Heleno SA, Martins A, Queiroz MJR, Ferreira IC, Bioactivity of phenolic acids: Metabolites versus parent compounds: A review. Food Chem., 2015; 173: 501-513.

14. Heleno SA, Ferreira RC, Antonio AL, Queiroz MJR, Barros L, Ferreira IC, Nutritional value, bioactive compounds and antioxidant properties of three edible mushrooms from Poland. Food Biosci., 2015; 11: 48-55.

15. Ivanova TS, Krupodorova TA, Barshteyn VY, Artamonova AB, Shlyakhovenko VA, Anticancer substances of mushroom origin. Exp Oncol., 2014; 36(2): 58-66.

16. Kalač P, A review of chemical composition and nutritional value of wild growing and cultivated mushrooms. J Sci Food Agric, 2013; 93(2): 209-218.

17. Kibby G, Fungal Portraits No. 52 Chanterelles and their allies. Field Mycology, 2012; 13(4): 111-117.

18. Lee KH, Morris-Natschke SL, Yang X, Huang R, Zhou T, Wu SF, Shi Q, Itokawa H, Recent progress of research on medicinal mushrooms, foods, and other herbal products used in traditional Chinese medicine. J Tradit Complement Med., 2012; 2(2): 1-12.

19. Li S, Wang A, Liu L, Tian G, Wei S, Xu F, Evaluation of nutritional values of shiitake mushroom (Lentinus edodes) stipes. J Food Meas Charact., 2018; 12(3): 2012-2019. 
FARMACIA, 2020, Vol. 68, 2

20. Li X, Wu Q, Xie Y, Ding Y, Du WW, Sdiri M, Yang $\mathrm{BB}$, Ergosterol purified from medicinal mushroom Amauroderma rude inhibits cancer growth in vitro and in vivo by up-regulating multiple tumor suppressors. Oncotarget, 2015; 6(19): 17832-17846.

21. Liu YT, Sun J, Luo ZY, Rao SQ, Su YJ, Xu R R, Yang YJ, Chemical composition of five wild edible mushrooms collected from Southwest China and their antihyperglycemic and antioxidant activity. Food Chem Toxicol., 2012; 50(5): 1238-1244.

22. Lu J, Qin JZ, Chen P, Chen Xi, Zhang YZ, Zhao SJ, Quality difference study of six varieties of Ganoderma lucidum with different origins. Front Pharmacol., 2012; 3: 1-5.

23. Mosman $\mathrm{T}$, Rapid colorimetric assay for cellular growth and survival: application to proliferation and cytotoxicity assays. J Immunol Methods.,1983; 65: 55-63

24. Muszyńska B, Grzywacz-Kisielewska A, Kała K, Gdula-Argasińska J, Anti-inflammatory properties of edible mushrooms: A review. Food Chem., 2018; 243: 373-381.

25. Özcan Ö, Ertan F, Beta-glucan content, antioxidant and antimicrobial activities of some edible mushroom species. J Food Sci Technol., 2018; 6(2): 47-55.

26. Popescu ML, Costea T, Gîrd CE, Fierăscu I, Balaci TD, Fierăscu RC, Antioxidant activity of Romanian Agaricus blazei Murill. and Agaricus bisporus J.E. Lange mushrooms. Farmacia, 2017; 65(3): 329-335.

27. Prasad S, Rathore H, Sharma S, Yadav AS, Medicinal mushrooms as a source of novel functional food. Int J Food Sci Nutr Diet., 2015; 4(5): 221-225.

28. Rathore H, Prasad S, Sharma S, Mushroom nutraceuticals for improved nutrition and better human health: a review. Pharma Nutrition, 2017; 5(2): 35-46.

29. Rosa LS, Silva NJA, Soares NCP, Monteiro MC, Teodoro AJ, Anticancer properties of phenolic acids in colon cancer-a review. J Nutr Food Sci., 2016; 6(2): 2-7.

30. Sánchez C, Reactive oxygen species and antioxidant properties from mushrooms. Synth Syst Biotechnol., 2017; 2(1): 13-22.

31. Shirazi MT, Gholami H, Kavoosi G, Rowshan V, Chemical composition, antioxidant, antimicrobial and cytotoxic activities of Tagetes minuta and Ocimum basilicum essential oils. Food science \& Nutrition, 2014; 2(2): 146-155.
32. Śliwka L, Wiktorska K, Suchocki P, Milczarek M, Mielczarek S, Lubelska K, Cierpial T, Łyżwa $\mathrm{P}$, Kiełbasiński P, Jaromin A, Flis A, Chilmonczyk Z, The comparison of MTT and CVS assays for the assessment of anticancer agent interactions. PloS one, 2016; 11(5): 1-17.

33. Smolskaite L, Venskutonis PR, Talou T, Comprehensive evaluation of antioxidant and antimicrobial properties of different mushroom species. LWT-Food Science and Technology, 2015; 60(1): 462-471.

34. Tawakoli PN, Al-Ahmad A, Hoth-Hannig W, Hannig M, Hannig C, Comparison of different live/dead stainings for detection and quantification of adherent microorganisms in the initial oral biofilm. Clin Oral Investig., 2013; 17(3): 841-850.

35. Tian J, Ma J, Ma K, Guo H, Baidoo SE, Zhang Y, Yan J, Lu L, Xu H, Wang S, $\beta$-Glucan enhances antitumor immune responses by regulating differentiation and function of monocytic myeloid- derived suppressor cells. Eur J Immunol., 2013; 43(5): 1220-1230.

36. Tubić J, Grujičić D, Jakovljević MR, Ranković B, Kosanić M, Stanojković T, Cirić A, MiloševićDjordjević OL, Investigation of biological activities and secondary metabolites of Hydnum repandum acetone extract. Farmacia, 2019; 67(1): 174-183.

37. Turfan N, Pekşen A, Kibar B, Ünal S, Determination of nutritional and bioactive properties in some selected wild growing and cultivated mushrooms from Turkey. Acta Sci Pol Hortoru, 2018; 17(3): 57-72.

38. Valverde ME, Hernández-Pérez T, Paredes-López O, Edible mushrooms: improving human health and promoting quality life. Int J Microbiol., 2015; 2015 : 1-14.

39. Vasdekis, EP, Karkabounas A, Giannakopoulos I, Savvas D, Lekka ME Screening of mushrooms bioactivity: piceatannol was identified as a bioactive ingredient in the order Cantharellales. Eur Food Res Technol., 2018; 244(5): 861-871.

40. Villares A, Mateo-Vivaracho L, García-Lafuente A, Guillamón E, Storage temperature and UV-irradiation influence on the ergosterol content in edible mushrooms. Food Chem., 2014; 147: 252-256.

41. Yang CH, Li RX, Chuang LY, Antioxidant activity of various parts of Cinnamomum cassia extracted with different extraction methods. Molecules, 2012; 17: 7294-7304. 